\title{
UPIORY [NIE]PAMIĘCI. ĆWICZENIA Z WIDMONTOLOGII POLSKIEJ
}

\section{MARCIN NAPIÓRKOWSKI, POWSTANIE UMARŁYCH. HISTORIA PAMIĘCI 1944-2014}

Monika Żychlińska

Uniwersytet Warszawski

Wiosną 2004 roku redakcja „Przeglądu Politycznego” zorganizowała dyskusję zatytułowana „Jakie Powstanie, jaka pamięć?”, w której wzięli udział wybitni polscy historycy i publicyści. Choć różnili się co do politycznych, społecznych i moralnych ocen zrywu, to łączyło ich przekonanie, że na przestrzeni lat pamięć powstania uległa konsolidacji i instytucjonalizacji. Andrzej Chojnowski nie bez rozczarowania stwierdził, że opublikowane po 1989 roku prace historyczne nie przyniosły nowego odczytania zrywu, a młode pokolenie badaczy nie przemówiło odrębnym głosem (2004: 78). Z kolei Tomasz Lubieński wyraził nadzieję, że w budowanym właśnie Muzeum Powstania Warszawskiego historia zostanie przedstawiona w sposób, który wzbudzi zainteresowanie młodych Polaków (tamże). Żaden z uczestników debaty nie przewidział, że obchody zbliżającej się sześćdziesiątej rocznicy wybuchu powstania zapoczątkują swoisty memory boom - nagły wybuch zainteresowania tematyka powstańczą oraz przyspieszenie dynamiki upamiętnienia tego wydarzenia historycznego.

Rocznicowe obchody okazały się mieć przełomowe znaczenie. Chodzi o coś więcej niż wykreowaną wówczas „modę na powstanie”. Od kilkunastu lat w polskim dyskursie publicznym obserwujemy wzrost znaczenia tematyki kommemoratywnej oraz powiązanej z nią tematyki narodowej. Przemianom uległa także sfera kulturowych praktyk upamiętnienia. Obecnie chętnie angażują się w nie zarówno instytucje, jak i osoby pry- 
watne. Pierwszego sierpnia syreny rozbrzmiewaja nie tylko w Warszawie, lecz także w innych miastach Polski. Muzeum Powstania Warszawskiego przygotowuje atrakcyjny, skierowany do różnych grup odbiorców program obchodów rocznicowych. Mieszkańcy stolicy zbieraja się, aby śpiewać powstańcze pieśni, biegają w powstańczych maratonach, ochoczo uczestnicza w inscenizacjach wydarzeń z 1944 roku. Można nawet kupić pościel z motywem zburzonej Warszawy.

Powstańczy boom pamięciowy, a także, mówiąc bardziej ogólnie, niespodziewana odnowa oraz ożywienie polskiego dyskursu historycznego ostatnich kilkunastu lat zaskakują oraz domagają się solidnego objaśnienia socjologicznego. Jakie sa przyczyny, mechanizmy i uwarunkowania tego boomu? Jeśli przyjąć, że praktyki pamięci są wyrazem rytualnego hołdu, jaki wspólnota składa samej sobie, to co zwrot pamięciowy mówi o nas samych - o kondycji i tożsamości polskiej wspólnoty wyobrażonej? W jaki sposób postrzega ona samą siebie, jak definiuje swoje miejsce w świecie, jakim ideałom i wartościom hołduje, jakie sa jej pragnienia, a jakie lęki?

Książka Marcina Napiórkowskiego Powstanie umarlych. Historia pamięi 1944-2014, wydana w serii historycznej Wydawnictwa Krytyki Politycznej, stanowi próbę kompleksowego ujęcia, a zarazem szczegółowego objaśnienia fenomenu pamięci powstania warszawskiego. Zadania tego podjął się młody profesor semiotyki kultury, którego pamięć biograficzna w niewielkim stopniu sięga PRL-u, a nawet transformacji ustrojowej, nieuwikłanego w ideologiczne spory tamtych czasów. Struktura pracy zbudowana jest wokół założenia, że pamięć powstania jest pamięcią pamiętającą samą siebie. Dzieje się tak dlatego, że bardziej niż do wydarzeń historycznych, odwołuje się ona do siebie samej - jest zależna od swojej ścieżki - historii (2016: 7). Jak dowodzi Autor, treści oraz nośniki pamięci zbiorowej wykazują długotrwały i autoreferencyjny charakter, który przejawia się w ciągłym przywoływaniu określonych kodów, motywów i figur (tamże).

Powracający co roku, rytualny spór o to, „czy powstanie miało sens”, interesuje Napiórkowskiego jedynie w kontekście odpowiedzi na pytanie o społeczno-kulturowe sensy, jakie owa pamięć generuje. Podejście Autora charakteryzuje typowa dla studiów nad pamięcia interdyscyplinarność tłumacząc procesy nadawania znaczeń przeszłości, czy też bardziej ogólnie, procesy wytwarzania kultury, sięga on po teorie i koncepcje socjologiczne, antropologiczne, psychologiczne, literaturo- i filmoznawcze, a nawet po mitologię grecka. Na uwagę zasługuje nie tylko imponująco szeroko zakreślony zakres tematyczny i chronologiczny pracy, lecz także bogaty i zróżnicowany materiał badawczy. Napiórkowski wciela się w rolę przewodnika 
po labiryncie historii pamięci powstania, przybliżając ją poprzez rozmaite figury pamięci - miejsca, zdarzenia, osoby i przedmioty (np. pomnik Gloria Victis na Cmentarzu Wojskowym na Powązkach, postać pułkownika Jana Mazurkiewicza „Radosława” czy hełm Andrzeja „Morro”), które łączą tę, spisaną na blisko pięciuset stronach, opowieść w całość. Odwołuje się przy tym do emocji i wyobraźni czytelników, pisząc z rozmachem typowym raczej dla powieści historycznych niż analiz naukowych.

Powstanie umarlych pokazuje, w jaki sposób na przestrzeni dziesięcioleci pamięć powstania nabierała znaczeń daleko wykraczających poza te, które można by przypisać zniszczeniu miasta oraz śmierci dziesiątek tysięcy jego mieszkańców. Teza, że pamięć powstania jest wielowątkową i wielogłosową opowieścią o przeszłości, powstała w wyniku sporu o charakterze politycznym, społecznym i moralnym, zostaje mocno podkreślona na kartach książki. Napiórkowski odczytuje kolejne warstwy pamięciowego palimpsestu: nieprzepracowaną żałobę lat 40., wymazywanie pamięci powstania w okresie stalinizmu, zafałszowania peerelowskiej polityki historycznej, a także potajemne kultywowanie pamięci czynu powstańczego, co stało się wyrazem sprzeciwu wobec komunistycznych władz oraz wyznacznikiem etosu demokratycznej opozycji. Autor wskazuje także na procesy uwalniania pamięci z podziału na narracje obozów władzy i opozycji po 1989 roku oraz zwrot pamięciowy, który dokonał się około 2004 roku wraz z otwarciem Muzeum Powstania Warszawskiego. Ostatnie dziesięciolecie to, zdaniem Napiórkowskiego, postępujące upolitycznienie pamięci powstania oraz wpisanie jej w efemeryczne struktury tzw. nowej kultury pamięci. Powstanie, które stało się tematem kultury popularnej, funkcjonuje obecnie jako swoista „marka” czy „franczyza”, podlegająca mechanizmom rynkowym gospodarki późnego kapitalizmu (2016: 353-356).

\section{/// Widma pamięci powstania warszawskiego}

Powstanie umarlych można zaliczyć do nurtu studiów widmontologicznych (z francuskiego hantologie $)^{1}$. Termin ten wprowadził Jacques Derrida

\footnotetext{
1 W Widmach Marksa termin ten tłumaczony jest jako ,widmontologia” (Derrida 2016b: 31). Widmontologia to także tytuł książki Andrzeja Marca (2015). Dowodzi on, że Derridiańska hantologie, będąca połączeniem czasownika hanter (nawiedzać) oraz ontologie (ontologia), jest przewrotną koncepcją ontologii. Agata Bielik-Robson nazywa Derridiańską bantologie "ontologia nawiedzenia” (2016: 35). Derrida chce zaburzyć paradygmat czystego istnienia - rozróżnienia na obecność i nieobecność. Pojęcie widma jest rozmyte i niedookreślone, ponieważ kpi sobie ono z zasad ontologii; istnieje w zróżnicowanych formach (Marzec 2015: 126-127). Inne stosowane nazwy to: hauntologia, duchologia oraz spektrologia, jednak jak zauważa Marzec, nie mają one wiele wspólnego z oryginalną koncepcją Derridy (tamże: 7-16 oraz 126-132). Tej ciekawej i wpływowej orientacji we
} 
w wykładach wygłoszonych w 1993 roku na Uniwersytecie Kalifornijskim w Riverside, a spopularyzował w zbiorze pism Widma Marksa. Zakorzeniona w dyskursie traumy metafora widma pozostaje nierozerwalnie związana z pojęciami straty i żałoby. Warto odnotować, że Derrida inspirował się dorobkiem dwojga francuskich psychoanalityków węgierskiego pochodzenia - Nicolasa Abrahama i Márii Török - badających międzypokoleniowe dziedziczenie pamięci traumatycznych doświadczeń (Davies 2013: 54). Stworzona przez nich koncepcja zjawy (phantom) dotyczyła wpływu głęboko utajonej traumy przodków na zaburzenia psychiczne ich dzieci i wnuków. Zjawa przodka nawiedza ego potomnego, żeby pilnować „rodzinnych sekretów" - nie dopuścić, aby informacje o traumatycznych, zazwyczaj wstydliwych wydarzeniach z przeszłości ujrzały światło dzienne. W rezultacie chory nie jest w stanie poznać przyczyn swego cierpienia (Derrida 2016a: 122-168; zob. także Davies 2013: 53-54).

Co odróżnia Derridowską koncepcję widma od koncepcji zjawy Abrahama i Török? Widmo, w przeciwieństwie do zjawy, ma ciało - jest paradoksalnym wcieleniem (Derrida 2016b: 24, zob. także Momro 2014: 472-473). Stanowi ono emanację żałoby, jest „...próbą ontologizacji resztek, sprawienia, by stały się obecne, przede wszystkim przez identyfikację zwłok i zlokalizowanie umarłego" (2016: 29). Ponadto, widmo jest stale obecne: choć widzi nas i obserwuje - czujemy na sobie jego wzrok - samo pozostaje niewidzialne, chyba że zdecyduje się objawić (tamże: 26). Obecność widma nie jest dla Derridy zagadką, którą należy rozwiązać, aby przywrócić czyjeś zdrowie psychiczne, francuski filozof traktuje ją raczej w kategoriach możliwości otwarcia się na tajemnicę. Derrida radzi zatem, aby z widmem rozmawiać i aby go słuchać, gdyż można w ten sposób uzyskać wgląd w rzeczywistość, do której nie mamy dostępu ze względu na brak odpowiedniego aparatu poznawczego. Zachęca także, aby wsłuchać się w głos widma, przemawiającego w imieniu tego, co choć należy do porządku przeszłości, stale pozostaje obecne w teraźniejszości (tamże: 29-30).

W tak zarysowanym kontekście staje się jasne, że tytuł Powstanie umartych stanowi grę znaczeń, zawierającą odniesienia zarówno do narodowego zrywu, jak i wizji (po)wstających z grobów żywych trupów. „Opowieść przedstawiona na kartach niniejszej książki - pisze Napiórkowski - to właśnie historia o stałej obecności nieopłakanych zmarłych w życiu kolejnych pokoleń i o politycznej aktywności, jaką umarli kontynuują zza grobu" (2016: 48). Fundamentem pamięci powstania jest bowiem - jak podkreśla

współczesnej humanistyce poświęcony jest numer tematyczny „Tekstów Drugich”, zatytułowany „Widmologie” (2/2016). 
Autor - nieprzepracowana zbiorowa trauma. Ze względu na ograniczenia polityczne i ideologiczne komunizmu polegli powstańcy nie zostali pożegnani we właściwy sposób. Przez następne dziesięciolecia nie sposób było kultywować ich pamięci. W widmontologicznej wizji, jaka przed czytelnikami roztacza Napiórkowski, psychika polskiej wspólnoty narodowej nawiedzona jest przez upiory przeszłości, które współcześnie przyjmuja postać kommemoratywych praktyk kulturowych (tamże: 346-349).

Autor stosuje się do zaleceń Derridy: zaprasza w gościnę widma pamięci, uważnie wsłuchuje się w ich głosy, stając się ich rzecznikiem, a nawet - trudno oprzeć się takiemu wrażeniu - przyjacielem. Czego zatem dowiaduje się od widm? Między innymi tego, że pamięć powstania kształtowała się pod wpływem dwóch sił interpretacyjnych, na kartach książki nazwanych toposami Pochodu i Konduktu. Pierwszy z nich, związany z ideologia postępu, nieustannego „marszu naprzód” oraz nieoglądania się na przeszłość, w tym radykalnego odrzucenia żałoby, wykorzystywany, czy wręcz narzucony został polskiemu społeczeństwu przez peerelowskie władze (2016: 51-59). Z kolei topos Konduktu, odpowiadający na psychologiczne potrzeby pogrążonych w żałobie rodzin, nakazywał zwrócenie się wstecz - ku przeszłości, grobom i zmarłym: „Topos Konduktu [...] podkreśla wagę przepracowania żałoby, która w wizji dziejów jest jedyną forma zapominania pozwalającą na powrót do codzienności” (tamże: 59). Rezultatem konfliktu pomiędzy toposami są dwie radykalnie różne postawy oraz repertuary praktyk pamięci, które przetrwały upadek komunizmu, a współcześnie przyjmują formę konfliktu pomiędzy „modernistami” i „tradycjonalistami” (tamże: 52-59).

\section{/// Pamięć zraniona - pamięć oporu}

Oryginalność intelektualnej propozycji Napiórkowskiego polega na tym, że patrzy na procesy kształtowania pamięci o powstaniu poprzez pryzmat kapitału symbolicznego ciał poległych powstańców. Autor nie szczędzi czytelnikom obszernych, przesyconych grozą i makabrą opisów powojennej Warszawy - miasta nawiedzonego przez śmierć, gdzie dokonywano masowych ekshumacji i inhumacji. Twierdzi jednak, że takie przywołanie pamięci jest konieczne, ponieważ poznanie założeń i mechanizmów „polityki martwych ciał” - polityki funeralnej władz komunistycznych względem żołnierzy Armii Krajowej - stanowi klucz do zrozumienia procesów nadawania znaczeń pamięci powstania, a także tego, w jaki sposób owa pamięć funkcjonuje współcześnie. 
Rozdziały zatytułowane Opowieści o śmierci dotycza politycznego procesu zawłaszczania zwłok przez państwo, który czasem przeradzał się w otwarty konflikt o ciała. Pogrążone w żałobie rodziny nadawały im znaczenie relikwii. Niedługo po wojnie zawiązały się społeczne komitety ekshumacyjne, w których działalność angażowali się rodzice - przede wszystkim matki ${ }^{2}$ - poległych powstańców. Dla władz komunistycznych szczątki powstańców stanowiły problem tak polityczny, jak ideologiczny. Liczba ekshumowanych ciał żołnierzy Armii Krajowej zadawała bowiem kłam propagandowej wersji historii, zgodnie z którą jej szeregi były nieliczne, a udział w zrywie pozbawiony znaczenia. Poprzez wprowadzenie formalnych utrudnień dążono do tego, aby do indywidualnych pochówków dochodziło jak najrzadziej. Wtedy też pojawiły się pogłoski o „kłamstwie powązkowskim" - fałszerstwach w identyfikacji ekshumowanych ciał oraz miejska legenda o porywaczach zwłok. W późniejszych dekadach „bitwa o ciała” przeniosła się w sferę symboliczną. Strategie upolitycznienia zwłok obejmowały kult prawomyślnych bohaterów - żołnierzy Armii Ludowej; kult niewinnych ofiar - poległej w powstaniu ludności cywilnej; a ostatecznie próbę symbolicznego zawłaszczenia wszystkich ofiar powstania (2016: 91).

Na kartach książki pamięć powstania zostaje określona mianem opozycyjnej-pamięci sprzeciwu, a nawet przeciw-pamięci. Termin ten pojawia się u Michela Foucaulta na oznaczenie alternatywnych narracji i reprezentacji przeszłości. Przeciw-pamięć, zwana także „pamięcią wykluczonych”, oznacza powstanie dyskursu opozycyjnego względem dyskursu dominującego, demaskującego jego fałszywe założenia (1977). Jak pisza Katarzyna Bojarska i Maria Solarska, aby przeciw-pamięć mogła się ujawnić, konieczne jest, aby znajdujący się na marginesie systemów zwyciężeni i wykluczeni uświadomili sobie swoje położenie - wtedy będą w stanie skutecznie wydobywać na światło dzienne to, co wyparte, pominięte i przemilczane w oficjalnym dyskursie (2014: 397). Z kolei Krzysztof Pomian zwraca uwagę na prywatny charakter przeciw-pamięci, do której dostęp mają tylko nieliczni: ,[...] jej pomnikami sa - w najlepszym przypadku - groby, które przychodzi się kwiecić, by uczcić ważną rocznicę lub Święto Zmarłych. Relikwie - ciała i przedmioty, które pozostały po zmarłych" (2006: 192).

\footnotetext{
$2 \mathrm{Na}$ temat roli matek w kształtowaniu i podtrzymywaniu pamięci powstania zob. rozdział: Warszawska Niobe. Jadwiga Romocka jako strażnička pamięci o powstaniu (2016: 120-124), oraz rozdział zawierający refleksje na temat rozmaitych wymiarów i przejawów upłciowienia pamięci powstania: Maskulinizacja i militaryzacja - wypieranie „kobiecej” pamięci o powstaniu (tamże: 288-303).
} 
Powstanie umarlych wskazuje na silnie antysystemowy potencjał historii pamięci powstania warszawskiego - jej symbolika przywoływana jest przez rozmaite grupy społeczne, które łączy poczucie ucisku i niesprawiedliwości, wynikające z negatywnej oceny sytuacji politycznej bądź dominującego dyskursu ${ }^{3}$. Za niezwykle ważne i cenne należy uznać spostrzeżenie, że pamięć powstania odgrywała - i nadal odgrywa - rolę mechanizmu decydowania o przynależności bądź wykluczeniu z uczestnictwa we wspólnocie. Jak zauważa Autor, wciąż obecny konflikt pomiędzy toposami Pochodu i Konduktu uniemożliwia dokonywanie bardziej zniuansowanych interpretacji oraz wyważonych ocen zrywu. Jeśli takowe interpretacje w ogóle się pojawiaja, to podlegaja krytyce z obu stron. Napiórkowski stawia diagnozę, że siedemdziesiąt lat po powstaniu pamięć tego wydarzenia bardziej Polaków dzieli, niż łączy - dzieli na dwa wzajemnie stygmatyzujące się obozy, utrwalające podział na „swoich” i „obcych”, na „tych, co z nami” i „tych, co przeciwko nam".

\section{/// Polemizując z tezami Powstania umartych}

Śmiałe tezy i interpretacje przedstawione na kartach Powstania umarlych wywołuja wiele pytań i zachęcaja do dyskusji. Moje największe wątpliwości budzi ostro zarysowane, dychotomiczne rozróżnienie pomiędzy toposami Pochodu i Konduktu, stosowane przez Autora do analizy różnych historycznych przypadków. Przeciwstawienie „utopizmu” i „tradycjonalizmu” jako konkurencyjnych postaw wobec przeszłości - razi konwencjonalnością i schematycznością. Jak zauważa Jerzy Szacki: „[...] w życiu społecznym niemożliwe jest ani «integralne dziedziczenie», ani «totalna innowacja», jest prawdą banalną, że zarówno zachowanie w całości dawnego sposobu życia, jak i rozpoczynanie życia społecznego od nowa, należą do sfery politycznych mitologii” (1971: 21). Rzeczywistość społeczna jest na tyle złożona i wieloaspektowa, że przejawy wyróżnionych przez Autora postaw rzadko zaobserwować można w czystej postaci. Sytuacja ta może prowadzić do mówiąc językiem Benjamina Schwartza - błędu niewłaściwego umieszczania konkretności (1984: 302). Zauważmy także, że choć Autor przywołuje główne założenia teorii i koncepcji traumy zbiorowej autorów takich jak: Cathy Caruth, Dominick LaCapra, Shoshana Feldman czy Jeffrey C. Ale-

\footnotetext{
3 Z własnych obserwacji dodam, że symbol Polski Walczacej pojawia się zarówno na stadionach piłkarskich, marszach ONR-u, jak i demonstracjach alterglobalistów. Jesienią 2016 roku pojawił się w czasie protestów przeciwko zaostrzeniu ustawy aborcyjnej. Powstańczą kotwicę, nad którą dorysowano dwie kropki - wywołujące skojarzenia z kobiecymi piersiami - opatrzono podpisem „Polka Walcząca”.
} 
xander, nie wykorzystuje ich eksplanacyjnego potencjału! Przede wszystkim nie operacjonalizuje ich na potrzeby prowadzonych badań albo stosuje jedynie w mikroskali (do analiz pojedynczych przypadków). Podstawowym punktem odniesienia rozważań Autora Powstania umarlych pozostaje binarne rozróżnienie na topos Pochodu i Konduktu.

Truizmem jest stwierdzenie, że nawet najbardziej postępowa władza - nawet najbardziej nowoczesny Pochód - nie jest w stanie zrezygnować ze strategicznego budowania odniesień do przeszłości w dyskursie publicznym. Pamięć społeczna jest źródłem nie tylko legitymizacji władzy, lecz także sensów, wartości i mitów tworzących podstawy ładu społecznego. Reprezentacje przeszłości służą także budowaniu tożsamości obywateli, sa źródłem definicji sytuacji, a także tworzą mnemoniczny kontekst działań i decyzji tak społecznych, jak politycznych (por. Lipiński 2014: 522). Sądzę, że zamiast przeciwstawienia znacznie ciekawsze byłoby pokazanie prób pogodzenia „tradycji” i „nowoczesności”: całego spektrum zjawisk będących rezultatem przenikania się wspomnianych toposów, a także wydobycie i poddanie analizie przypadków, które trudno jest sklasyfikować ze względu na ich niejednoznaczność.

Wątpliwości budzi także powiązanie toposu Konduktu z orientacją psychoanalityczną oraz rozwijanym i popularnym przede wszystkim na Zachodzie terapeutycznym dyskursem traumy i zdrowienia. Wielokrotnie na kartach książki wyrażane jest przekonanie, że gdyby tylko warunki historyczne pozwoliły na wykonanie „pracy żałoby” oraz „przepracowanie traumy”, psychika polskiej wspólnoty narodowej nie zostałaby opanowana przez upiory przeszłości. Czy aby na pewno? W swoich rozważaniach Autor zdaje się nie brać pod uwagę kulturowych ograniczeń zastosowania kategorii dyskursu terapeutycznego do analizy zjawisk pamięci w Polsce. Pomija odwołania do polskiej tradycji romantycznej, zwłaszcza jej martyrologiczno-mesjanistycznego wcielenia, będącego, jak od wielu lat podkreśla Maria Janion, polską dominantą kulturowa, niezwykle ważnym generatorem sensów i znaczeń (zob. np. 1998, 2006). O wampirycznym charakterze polskiej wspólnoty narodowej badaczka romantyzmu pisała wielokrotnie. Należący do najbardziej uniwersalnych w kulturze mit wampira - powstającego z grobu, spragnionego krwi nieboszczyka - wywodzi się ze słowiańskich wierzeń ludowych (2006: 64-67). Wampir śmiertelnie wykańcza swoje ofiary, chce bowiem panować nad nimi w sposób absolutny. Osoby przez niego zaatakowane same stają się - żyjącymi na granicy świata żywych i umarłych - upiorami (Janion 2002: 8). Warto zatem się zastanowić, 
czy w polskim kontekście kulturowym widmontologia nie przyjmuje postaci romantycznego mesjanizmu?

Postawię tezę, że topos Konduktu nie zakłada przepracowania traumy, lecz jej ciagłe odtwarzanie, czemu sprzyja gloryfikowanie cierpienia, którego metafizyczny sens - zrozumiały jedynie dla uczestników tej żałobnej procesji - ma objawić się w dłuższej perspektywie historycznej. Potwierdzenie tej tezy znaleźć można nie tylko w pracach Janion czy Lubieńskiego $(1978,2004)$, lecz także francuskiego dziennikarza Jeana-Françoisa Steinera, który w latach 70. ubiegłego wieku prowadził wywiady z dowódcami powstania. W książce Warszawa: powstanie 44 Steiner przedstawił ich zbiorowy, pogłębiony portret psychologiczny. Dowódcy wychowani na wielkiej literaturze romantycznej traktowali zryw w kategoriach hekatomby - gigantycznej ofiary z ludzi i miasta, złożonej w imię odkupienia świata. Jak zauważył jeden z generałów: „Pewnego dnia Polska cierpiąca i udręczona, skazana jak feniks z popiołów na ciągłe spalanie i odradzanie się, znajdzie swe miejsce w świecie, miejsce, którego już nikt i nic nie zakwestionuje" (Steiner 1984: 104). Wypowiedź stanowi ilustrację mesjanistycznego sposobu nadawania znaczeń rzeczywistości, kompletnie nieprzystającego do myślenia psychoanalitycznego. Postulat przepracowania traumy znajduje się poza horyzontem intelektu i wyobraźni mówiącego - skoro powstanie nie zostaje zdefiniowane jako trauma, nie ma czego przepracowywać. Wypowiedź wyraża także przekonanie, że ofiara niosąca odrodzenie poprzez śmierć jest źródłem honoru i nobilitacji. Wzrok mesjanistycznego Konduktu skierowany jest ku przeszłości, a powtarzanie tragicznych doświadczeń rozumiane jako wypełnianie - mającego przynieść zbawienie nie tylko narodowi polskiemu, lecz całej ludzkości - przeznaczenia.

Przyjrzyjmy się pamięci bardziej współczesnego wydarzenia. W przypadku katastrofy smoleńskiej warunki do przepracowania traumy zostały spełnione - zmarli zostali opłakani i pożegnani z najwyższymi, należnymi im honorami państwowymi. Na kilka tygodni kwietnia 2010 roku polski rząd zmienił się w całkiem sprawnie funkcjonujące biuro pogrzebowe, a trwające wiele dni uroczystości żałobne angażowały, choć w różny sposób i w różnym stopniu, całe polskie społeczeństwo. A jednak ten rozdział historii nie został zamknięty - katastrofa, podobnie jak ciała jej ofiar, zostały upolitycznione, a żałoby po tragedii nie sposób zakończyć. Sytuację tę można tłumaczyć obecnością mesjanistycznego Konduktu w polskiej kulturze.

W dramatycznym liście opublikowanym przez „Tygodnik Powszechny” w październiku 2016 roku Małgorzata Rybicka, wdowa po tragicznie 
zmarłym w katastrofie smoleńskiej Arkadiuszu Aramie Rybickim, prosiła władze państwowe o uszanowanie godności jego doczesnych szczątków: „Nie zgadzam się na używanie ciała mojego męża do celów politycznych. Nie zgadzam się na dręczenie mnie i mojej rodziny poprzez wywoływanie u nas ponownej żałoby". Umieszczone w tym jakże współczesnym kontekście, spisane na kartach Powstania umartych refleksje na temat obecności zmarlych w polskim życiu politycznym, a także budowania przez żywych tożsamości w relacji do pamięci traumatycznych wydarzeń przeszłości, wskazują na ważny wzór kulturowy. Ekshumacje można uznać za emanację polskiego romantyzmu wraz z charakterystycznym dla niego dążeniem do przekroczenia kulturowego tabu śmierci (zob. np. Janion 2006: 125-130).

Kolejna uwaga dotyczy struktury pracy: choć zakres czasowy Powstania umarlych obejmuje lata 1944-2014, to około trzy czwarte książki dotyczy historii pamięci powstania w PRL-u, przede wszystkim dwóch pierwszych jego dekadach, z naciskiem na okres powojenny. Nie ulega wątpliwości, że temat został świetnie opracowany zarówno pod względem zebranego materiału, jak i wnikliwych, miejscami wirtuozerskich interpretacji, takich jak np. intertekstualne odczytanie tzw. trylogii wojennej Andrzeja Wajdy - filmów nawiązujących do tematyki powstańczej. Na tym jednak tle rozdziały poświęcone najnowszym dziejom pamięci powstania, w szczególności przemianom, jakie przeszła ona w ciagu ostatniej dekady, sprawiają wrażenie dopisanego w pośpiechu, dość pobieżnego Postscriptum. Wielokrotnie powtarzana teza, że aby właściwie zrozumieć współczesne funkcjonowanie pamięci powstania, należy dokładnie poznać proces jej historycznego kształtowania (stąd tak obszerne potraktowanie historii pamięci powstania w PRL-u), wydaje się tyleż słuszna, co nieprzekonująca. Każdy choć trochę refleksyjny uczestnik polskiej kultury pamięci zdaje sobie sprawę, że - czy tego chce, czy nie - bierze udział w pamięciowym boomie: zjawisku zasadniczo nowym, podlegajacym nowym uwarunkowaniom i mechanizmom.

W Powstaniu umarlych brakuje odpowiedniego klucza do interpretacji najnowszych zjawisk i procesów kształtowania się pamięci powstania. Zadanie to nie jest zresztą łatwe - jak zauważa Autor, współczesna rzeczywistość społeczno-kulturowa staje się coraz bardziej rozproszona i nieoczywista, coraz trudniejsza do całościowego odczytania. Z roku na rok przybywa zarówno oficjalnych, jak i oddolnych inicjatyw upamiętniania zrywu. Napiórkowski stara się je skatalogować oraz podejmuje próby ich interpretacji, wydaje się jednak bezradny wobec ich wielości i zróżnicowania. Ostatnie rozdziały książki wypełniają luźne obserwacje oraz skojarzenia Autora, a także jego osobiste odczucia i interpretacyjne intuicje. $\mathrm{Na}$ 
koniec Napiórkowski porzuca rolę uczonego dekonstruującego powstańcze mitologie i fantazmaty na rzecz roli flâneura, zabierającego czytelników na nostalgiczny spacer po Warszawie. Choć wędrówka ma służyć analizie relacji między przestrzenną organizacją miasta a praktykami kulturowymi jego mieszkańców, ostatecznie przybiera formę poetyckiej opowieści o pięknej i wzniosłej przeszłości miasta (2016: 401-430).

Sądzę, że zrozumienie współczesnego funkcjonowania pamięci powstania zostałoby pogłębione, gdyby Autor Powstania umarlych w większym stopniu uwzględnił wnioski z przeprowadzonych dotychczas badań nad rozmaitymi zagadnieniami tego zjawiska. Na marginesie należy zauważyć, że przedstawiony na początku tomu zarys stanu badań stanowi zaledwie próbę owego zarysu, ogranicza się bowiem do kilku najważniejszych publikacji. Nasuwa się podejrzenie, że dokonując własnych interpretacji, Autor nie do końca zdaje sobie sprawę, czy i w jakim stopniu korzysta z interpretacji i analiz już istniejaccych. Druga kwestia to wspomniany brak zakorzenienia prezentowanych tez w empirii. Uzasadnione staje się np. pytanie o to, skąd Autor czerpie informacje na temat planów i intencji twórców Muzeum Powstania Warszawskiego, skoro nie prowadził kwerendy archiwalnej w tej instytucji ani nie odwołuje się do wniosków zawartych w opublikowanych na ten temat pracach?

\section{/// Wyjaśnić zagadkę powstańczego boomu pamięci!}

Na koniec powróćmy do wyjściowego pytania o mechanizmy i uwarunkowania powstańczego boomu pamięciowego. Nie objaśniają tego ani zastosowane przez Autora Powstania umarlych antropologiczno-psychologiczne koncepcje zbiorowej traumy i żałoby, ani też teza o długim trwaniu paradygmatu romantycznego w polskiej kulturze. Socjolog Lech Nijakowski łączy wzrost znaczenia pamięci przeszłości w polskim dyskursie publicznym z prowadzona przez Prawo i Sprawiedliwość polityka, która określa mianem „ofensywy martyrologicznej IV RP”. Za jej symboliczny początek uznaje wrzesień 2004 roku, gdy polityka historyczna została zapisana w programie partii (2008: 190). Zdaniem Nijakowskiego sprowadziła ona postulat przywrócenia narodowej dumy do promowania narodowej megalomanii. Stworzono wyidealizowany - bohaterski i „pozbawiony ciemnych szram” - obraz historii Polski oraz narodu polskiego jako wspólnoty etnicznie i religijnie spójnej, zjednoczonej wokół katolickich wartości i kultu romantycznych bohaterów (tamże: 190-241). Czy jednak treść oraz dynamika zwrotu pamięciowego - makrozjawiska społecznego - zależy 
od działania jednej siły, nawet jeśli jest nią partia rządząca oraz forsowana przez nią polityka pamięci? Należy postawić pytanie o warunki, które przesądziły o sukcesie tak sformułowanego programu pamięci - prawdopodobnie odpowiadał on na ważne społecznie potrzeby lub oczekiwania, które pojawiły się wraz z początkiem lat dwutysięcznych. Zauważmy także, że pamięciowy boom utrzymał się pomimo odejścia Prawa i Sprawiedliwości od władzy w 2007 roku.

Sądzę, że objaśnienie tego arcyciekawego zjawiska można by rozpoczać od stworzenia mapy pola pamięci kulturowej powstania warszawskiego oraz zidentyfikowania jego najważniejszych aktorów, w tym określenia zajmowanego przez nich miejsca w strukturze społecznej oraz dostępu do rozmaitych zasobów - od symbolicznych po materialne. Kolejny krok obejmowałby analizę roszczeń formułowanych przez aktorów - w imieniu jakich wspólnot i jakich wartości występują? Jakimi kulturowymi skryptami powstania warszawskiego - a także pamięci tego wydarzenia - się posługują? Jakie cele chcą osiagnąć? Do kogo kieruja swój przekaz? Jakie emocje chcą wywołać u odbiorców? Jakie są ich relacje z innymi aktorami w polu pamięci - z kim wspólpracuja (np. czy korzystaja ze wsparcia instytucjonalnego Muzeum Powstania Warszawskiego lub też innych instytucji kultury, organizacji pozarządowych lub partii politycznych), a może działają zupełnie samodzielnie?

Powyższe pytania dotyczą jedynie przykładowych zagadnień, które można uwzględniać, projektując badanie powstańczego boomu pamięciowego. Przyjęcie zaproponowanej konceptualizacji wiązałaby się z zastosowaniem etnograficznych metod badawczych, być może z fizycznym wyruszeniem w teren. Ponieważ nie sposób w pełni wyczerpać tematu, należałoby wybrać najważniejsze lub najciekawsze przejawy badanego zjawiska. Wybór jest ogromny, można np. przyjrzeć się działalności powstańczych grup rekonstrukcyjnych, zanalizować reprezentacje powstania w najnowszej literaturze dziecięcej i młodzieżowej lub zastanowić się nad praktyka tatuowania na ciele symboli powstańczych $\mathrm{w}$ perspektywie pracy tożsamościowej. Tożsamościowo-biograficzny aspekt zainteresowania pamięcia powstania wydaje się szczególnie ciekawy i wymagający objaśnienia. Co powoduje, że Polacy gotowi są angażować swe różne cenne zasoby w działania na rzecz upamiętnienia powstania? Jakie wspólnotowo-tożsamościowe korzyści czerpią z takiej aktywności? Pominięcie tych pytań spowoduje, że wyjaśnienie powstańczego boomu pamięciowego będzie niepełne.

Podsumowujac, Powstanie umartych jest praca niewatpliwie ciekawa, domagającą się kontynuacji oraz stanowiącą inspirację dla przyszłych badań. 
Jest to także ważny głos w niekończącej się dyskusji na temat pamięci powstania oraz - jak sądzę - próba odnalezienia własnego miejsca w owej przestrzeni dyskursywnej przedstawiciela młodego pokolenia badaczy. $\mathrm{Na}-$ wet jeśli można mieć pewne wattpliwości co do sposobu przeprowadzenia próby, to sama gotowość i wysiłek jej podjęcia zasługuja na szacunek. I choćby z tego powodu warto Powstanie umarlych przeczytać.

Bibliografia:

/// Bielik-Robson A. 2016. Uśmiech Widma bez Ciała: kabalistyczna baśń z. Derrida w tle, „Teksty Drugie”, nr 2, s. 15-37.

/// Bojarska K., Solarska M. 2014. Kontr-pamiéć, [w:] Modi memorandi. Leksykon kultury pamieci, red. M. Saryusz-Wolska, R. Traba, Wydawnictwo Naukowe Scholar, s. 396-402.

/// Davies C. 2013. „État Présent”. Hauntology, Spectres and Phantoms, [w:] The Spectralities Reader: Ghosts and Haunting in Contemporary Cultural Theory, red. M. del Pilar Blanco, E. Peeren, Bloomsbury Academic, s. 53-59.

/// Derrida J. 2016a. Fora. „Kanciaste stowa” Nicolasa Abrahama i Márii Török, tłum. B. Brzezicka, „Teksty Drugie”, nr 2, s. 122-168.

/// Derrida J. 2016b. Widma Marksa. Stan dtugu, praca załoby i nowa Miedzynarodónka, tłum. T. Załuski, Wydawnictwo Naukowe PWN.

/// Foucault M. 1977. Language, Counter-Memory, Practice: Selected Essays and Interviens, red. D.F. Bouchard, tłum. D.F. Bouchard, S. Simon, Cornell University Press.

/// Grochowski G. 2016. Numer nawiedzony, „Teksty Drugie”, nr 2, s. 7-13.

/// Janion M. 1998. Placz generała. Eseje o wojnie, Wydawnictwo Sic!

/// Janion M. 2002. Wampir. Biografia symboliczna, Słowo/Obraz Terytoria.

/// Janion M. 2006. Niesamowita Stowiańszczyzna. Fantazmaty literatury, Wydawnictwo Literackie.

/// Lipiński A. 2014. Władza, [w:] Modi memorandi. Leksylkon kultury pamieci, red. M. Saryusz-Wolska, R. Traba, Wydawnictwo Naukowe Scholar, s. $518-522$. 
/// Lubieński T. 1978. Bić sie cæy nie bić? O polskich ponstaniach, Wydawnictwo Literackie.

/// Lubieński T. 2004. Ani tryumf, ani zgon. Szkice o powstaniu warszanuskim, Wydawnictwo Nowy Świat.

/// Napiórkowski M. 2016. Powstanie umarlych. Historia pamięci 1944-2014, Wydawnictwo Krytyki Politycznej.

/// Nijakowski L.M. 2008. Polska polityka pamieci. Esej socjologiczny, Wydawnictwa Akademickie i Profesjonalne.

/// Marzec A. 2015. Widmontologia. Teoria filozoficzna i praktyka artystyczna ponowoczesności, Fundacja Nowej Kultury Bęc Zmiana.

/// Momro J. 2014. Widmontologie nowoczesności. Genezy, Wydawnictwo Instytutu Badań Literackich PAN.

/// Pomian K. 2006. Historia - nauka wobec pamieci, tłum. H. Abramowicz, J. Pietrzak- Thebault, Wydawnictwo Uniwersytetu Marii Curie-Skłodowskiej.

/// Rybicka M. 2016. Uszanujcie godność ofiar!, „Tygodnik Powszechny”, 14 października 2016. https://www.tygodnikpowszechny.pl/uszanujcie-godnosc-ofiar-36199; dostęp: 12.01.2017.

/// Schwartz B. 1984. Granice dychotomii „tradycja-nowoczesnosí” jako kategorii wyjaśniajacych. Sytuacja intelektualistów chińskich, [w:] Tradycja i nowoczesność, red. J. Szacki, J. Kurczewska, Czytelnik, s. 302-332.

/// Steiner J-F. 1984. Warsqawa: powstanie 44, tłum. M. Kłyszewska, Wydawnictwo Krag.

/// Szacki J. 1971. Tradycja: przeglad problematyki, Państwowe Wydawnictwo Naukowe.

/// 2004. Historia do rewizji. Warszawa '44, „Przegląd Polityczny”, nr 66, s. 77-86. (Dyskusja pod tytułem „Jakie Powstanie, jaka pamięć?” 26 kwietnia 2004; udział wzięli Włodzimierz Borodziej, Andrzej Chojnowski, Andrzej Friszke, Tomasz Lubieński, Marian Wojciechowski; do druku przygotował Andrzej Chojnowski.) 